\title{
8
}
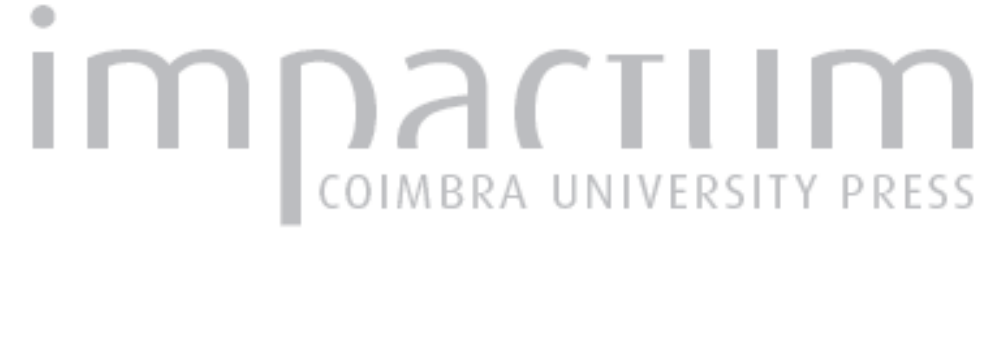

\section{Pathological evidence in the Pre-Columbian human remains from the Lee Collection (Jamaica)}
Autor(es):
Santos, Ana Luísa; Allsworth-Jones, Philip; Rodriques, Esther
Publicado por: CIAS - Centro de Investigação em Antropologia e Saúde
URL persistente:
URI:http://hdl.handle.net/10316.2/41266
DOI:
DOI:http://dx.doi.org/10.14195/2182-7982_19_10
Accessed : $\quad$ 26-Apr-2023 15:37:26

A navegação consulta e descarregamento dos títulos inseridos nas Bibliotecas Digitais UC Digitalis, UC Pombalina e UC Impactum, pressupõem a aceitação plena e sem reservas dos Termos e Condições de Uso destas Bibliotecas Digitais, disponíveis em https://digitalis.uc.pt/pt-pt/termos.

Conforme exposto nos referidos Termos e Condições de Uso, o descarregamento de títulos de acesso restrito requer uma licença válida de autorização devendo o utilizador aceder ao(s) documento(s) a partir de um endereço de IP da instituição detentora da supramencionada licença.

Ao utilizador é apenas permitido o descarregamento para uso pessoal, pelo que o emprego do(s) título(s) descarregado(s) para outro fim, designadamente comercial, carece de autorização do respetivo autor ou editor da obra.

Na medida em que todas as obras da UC Digitalis se encontram protegidas pelo Código do Direito de Autor e Direitos Conexos e demais legislação aplicável, toda a cópia, parcial ou total, deste documento, nos casos em que é legalmente admitida, deverá conter ou fazer-se acompanhar por este aviso.

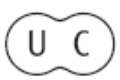


Antropologia Portuguesa

Volume $19 \cdot 2002$

Departamento de Antropologia | Universidade de Coimbra 


\title{
Pathological evidence in the Pre-Columbian human remains from the Lee Collection (Jamaica)
}

\author{
Ana Luísa Santos ${ }^{1}$, Philip Allsworth-Jones ${ }^{2}$, Esther Rodriques ${ }^{3}$ \\ 'Departamento de Antropologia \\ Universidade de Coimbra \\ 3000-056 Coimbra, Portugal \\ ${ }^{2}$ Department of History and Archaeology \\ The University of the West Indies - UWI \\ Mona Campus, Kingston 7, Jamaica \\ ${ }^{3}$ Lee Project, Archaeological Laboratory, UWI \\ Mona Campus, Kingston 1, Jamaica \\ alsantoseci.uc.pt
}

Abstract The Archaeology Laboratory in the Defartment of History and Archaeology at UWI has housed the James W. Lee Collection of Arawak artefacts and human remains since 2000 . A complete database is being prepared by two of the authors (PAJ and ER) as part of a project under the auspices of the Jamaica Bauxite Institute. The collection spans a total of 265 sites and was collected over a 27 year period (1959-1986). Eight caves and 16 open-air sites produced human remains, with a minimal number of 46 individuals. Despite adverse taphonomic factors, age and sex estimation, metric analyses, and pathological case descriptions, could be carried out in a number of cases. This paper will focus on the paleopathological evidence. Two skulls (EC12, Bull Savannah \#2 cave, St. Elizabeth, and CC15, Taylor's Hut cave, Clarendon) were artificially modified. CC15 was found inside a bowl. At E12 (Black River West) an increase in thickness in two fragments of tibiae and in one fibula is regarded as a pathological condition, possibly related to treponematosis. Signs of degenerative joint diseases, such as eburnation in an atlas and in a humerus, and osteoarthritis in several bones, were detected at $\mathrm{J} 1$ (Hartfield) and JC7 (Spot Valley cave). Finally a case of agenesis exists in the right decidual incisor in a mandible of a juvenile with an age-at-death around 4 years (Y4, Rio Nuevo, St. Mary). This study is a contribution to the understanding of extinct pre-Columbian populations in the Caribbean region.

Key words Taino/Arawak; cranial modification; treponematosis; arthritis; dental agenesis; Jamaica. 
Resumo Os artefactos e os restos osteológicos recolhidos, entre 1959 e 1986, por James Lee em 265 locais arqueológicos transitaram em 2000 para o Arclincology Laboratory, Department of History and Archaeology, University of West Indies, Jamaica. Num projecto apoiado pelo Jamaica Bnuxite Institute dois dos autores (PAJ e ER) preparam uma base de dados da colecção. Em oito grutas e 16 jazidas a céu aberto existiam restos humanos que correspondem a um número mínimo de 46 indivíduos. Apesar da adversidade da tafonomia puderam ser avaliados parâmetros paleodemográficos e referenciadas algumas patologias: modificações em dois crânios (CC15, Gruta de Taylor's Hut, e EC12, Gruta de Bull Savannah \#2) um dos quais foi encontrado dentro de um vaso; evidências prováveis de treponematoses em fragmentos de dois fémures e duma tíbia de E12 (Black River West); sinais de doenças degenerativas das articulações, nomeadamente eburnação num atlas e num úmero, no material proveniente de J1 (Hartfield) e de JC7 (Gruta de Spot Valley); e, agenesia do incisivo direito decidual na mandíbula de uma criança com cerca de 4 anos de idade à morte (Y4, Rio Nuevo). Este estudo é, assim, uma contribuição para o conhecimento das populaçōes pré-Colombianas extintas das Caraibas.

Palavras-chave Taino/Arawak; modificações cranianas; treponematoses; agenesia dentária; Jamaica.

\section{Introduction}

The study of human remains is fundamental for the understanding of past populations and is even more challenging in prehistoric and extinct groups such as the case of the Arawak/Taino, known as the first inhabitants of Jamaica. The earliest date evidencing their existence in Jamaica is about $650 \mathrm{AD}$ (Lee, 1980) and by the second half of the 17 th century AD they became extinct due to various factors including diseases (Lee, 1964; Kiple and Ornelas, 1996). For their means of subsistence they depended on cassava agriculture, hunting mainly for hutia, fishing and shellfish collecting as well as wild plant gathering (Sturtevant, 1961; Silverberg et al., 1972). Known artefacts consist mainly of pottery, but there were also decorative items, and some caves have petroglyphs and pictographs (Duerden, 1897; Lee, 1990). 
Skeletal remains from this population were described as early as the nineteenth century. In 1891, Flower published a study of material found in the Pedro Bluff cave and belonging to the Kingston Museum. A few years later, in April 1895, human bones from more than 20 individuals were counted in a cave at Halberstadt Estate in the Port Royal Mountains (Duerden, 1895; Flower, 1895; Duerden, 1897). The presence of Arawak osteological findings was also revealed in Richmond Hill and Botany Bay caves (Duerden, 1897). After these early discoveries there were no further publications on this subject for many years. Later, in the 1960s Taino osteological remains were reported from Cambridge Hill cave (Harper, 1961/2).

With the arrival of James Lee, a professional geologist and amateur archaeologist, a new period started. Active for many years in Jamaica, he mapped Arawak settlements all over the island, and between 1959 and 1986 recorded a total of 265 sites, 201 middens and 64 caves, with full geographical coordinates (Allsworth-Jones et al., in prep.). The artefacts, faunal and human remains collected, mainly surface findings, were presented to the University of the West Indies by Dr. Lee in the year 2000 and are now stored in the Archaeology Laboratory in the Department of History and Archaeology (The James W. Lee Collection of Arawak Artefacts, 2000). A complete inventory and database of the Lee Collection is being prepared by two of the authors (PAJ and ER) as part of a project funded by the Kaiser Jamaica Bauxite Company (KJBC) and Alumina Partners of Jamaica (ALPART) under the auspices of the Jamaica Bauxite Institute (Allsworth-Jones et al., in prep.). During this process the presence of human bones and teeth was recorded from a total of eight caves and 16 open air sites. Despite the taphonomic alterations and fragmentation of these materials, parameters such as age and sex estimation, metric analyses, and the study of pathologies could be carried out in a number of cases (Santos, 2003).

More recently, new sites were recognized and systematic excavations performed. In the Kingston area work was done at Chancery Hall (K11) (Allsworth-Jones et al., 2001), and extensive excavations were undertaken at Green Castle (near Annotto Bay) 
where two primary burials were found (Santos, 2001; AllsworthJones and Wesler, 2003).

This essay focuses attention on paleopathological evidences found in the human remains from the Lee Collection. Thus, this study could improve our knowledge of the Arawak/Taino in Jamaica, hitherto based mainly on ethnohistorical records.

\section{Materials and methods}

The sample examined concerns commingled human bones and teeth from the Lee Collection. All together there were more than 2800 bones and around 100 teeth, but not all of these could be identified or linked to specific locations. Identified remains were recovered from 24 named Lee sites: eight caves and 16 open air sites. This material could cover a 900 year period from about 600 to $1500 \mathrm{AD}$ and at least two cultural episodes (Redware and White Marl, in the Jamaican terminology) could well be represented (Allsworth-Jones et al., in prep.).

In the study of this material a minimal number of 46 individuals from both sexes and ages from less than 6 months to adults were recorded (Santos, 2003). The full description of the material is available at the Lee Collection CD-ROM database (Allsworth-Jones et al., in prep.). The current study deals with pathological cases. As a methodological approach, the skeletal remains were subjected to macroscopic visual inspection to identify all occurrences of bony alteration. In addition to naked eye observations the differential diagnosis of several specimens included radiographs examination thanks to the kind collaboration of The University Hospital of the West Indies (Mona, Kingston).

\section{Lesions description and discussion}

Due to the disarticulated nature of the bones, the observations are presented by types of pathologies considered. 


\section{Skulls artificially modified}

Intentional alteration of the skull is a cultural practice with a wide distribution (Harper, 1961/2; Aufderheide and Rodríguez-Martín, 1998). In the Lee Collection evidences of modification arises in the two well preserved crania. Interesting, both were found inside caves: CC15B66.1 found in the Taylor's Hut cave in Clarendon and EC12B21B.1 from Bull Savannah \#2 cave in St. Elizabeth.

The cranium CC15B66.1 was found inside a bowl and photographed by Lee (1971-3:6) at the time which revealed that it was a secondary burial (The James W. Lee Collection of Arawak Artefacts, 2000). It is a very well preserved skull, only the occipital condyles were missing and the orbits suffered postmortem damage (Figure 1). It shows a frontal flattening and parietal expansion, also designated as "parallelo-fronto-occipital" or "tabular oblique" according to Buikstra and Ubelaker (1994:161) representations. In what concerns sex diagnosis, according to Buikstra and Ubelaker's (1994), features this individual seems to be most probably a male. The evaluation of the suture closure is a feature commonly used for age at death estimation. However, in artificially deformed skulls its application could be questioned as well as when there are supra numeric bones in the sutures, as in this case in the lambdoid. Thus, it is preferable to consider it as an adult individual. Moreover, no teeth were preserved on the maxilla: on both sides, the anterior teeth were missing most likely postmortem, while the second premolars, the first and second molars were lost antemortem. On the right side the alveolar bone is very thin in the region of the third molar, which could result from antemortem tooth loss or due to agenesis of this tooth. Moreover, a radiograph of the maxilla revealed that there is no impacted tooth. Conversely, on the left side the alveolar bone is slightly damaged which permits the third molar crown visualisation. 

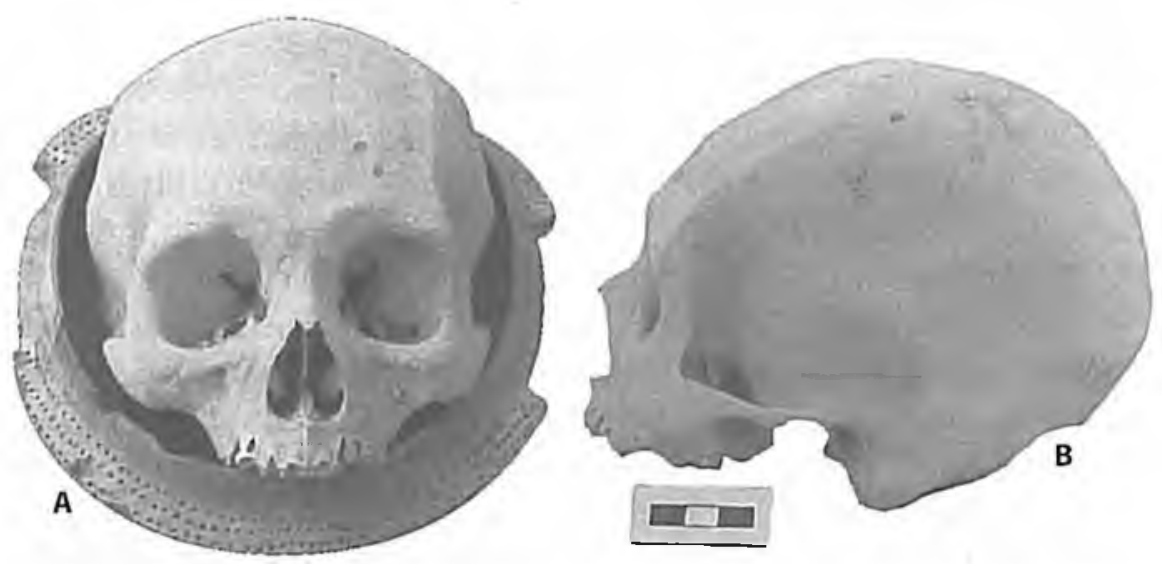

Figure 1.A. Bowl with the skull CC15B66.1 inside. B. Left lateral view of artificially modified skull from the Taylor's Hut cave.

The cranium EC12B21B.1 has the face bones, the frontal, the parietals, and the right temporal (mastoid process absent) present (Figure 2). The sphenoid, the ethmoids and the zygomatics were also partially destroyed. The skull was lying on its base, and the base has been partially destroyed including the occipital, part of the left temporal and part of the right one. The palate was damaged and no teeth were preserved. In general, this individual is very fragile due to postmortem destruction. The endocranial surface is also affected by taphonomic factors, namely discolouration and possible termite action that led to bone destruction. The rear part of the parietals is discoloured and shows bone destruction which includes texture and shape changes. This individual presents a very flat frontal and parietal expansion, similar to CC15B66.1 but more pronounced. Despite the poor state of preservation sexual diagnosis was attempted. According to Buikstra and Ubelaker's (1994:20) descriptions all the visible characteristics were male features. However, this diagnosis should be used only as an indication. The same care is necessary for ageat-death estimation. However, the pattern of suture observed is more common in young and middle aged adults. 


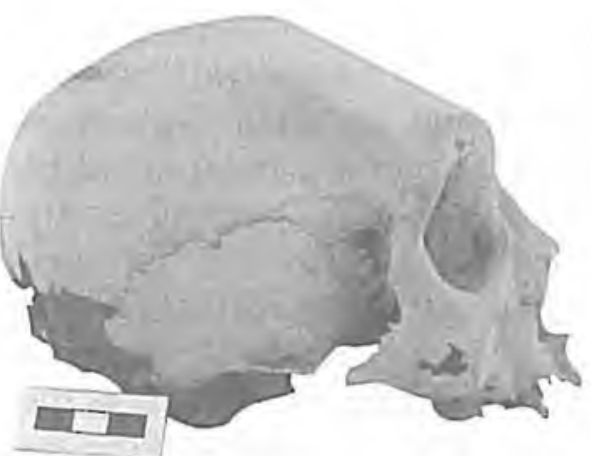

A

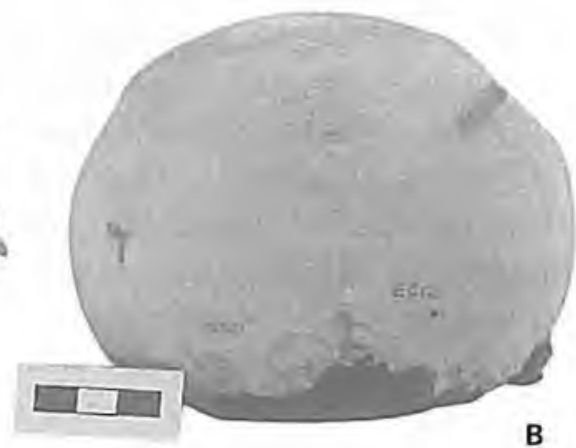

Figure 2. A. Right lateral view of the skull EC12B21B.1 from Bull Savannah \#2 cave (St. Elizabeth Parish). B. Posterior view showing parietal expansion.

Frontal flattening seems to have been a common feature in the Arawak/Taino culture. According to historic writings they had broad heads (Harper, 1961/2; Rouse, 1963:522 in Drusini et al., 1987), and the osteological remains confirm this cultural practice. One artificially deformed cranium was reported at Pedro Bluff cave by Flower (1891) and this feature occurred in five (out of six adult skulls) from Halberstadt which he was able to study (Flower, 1895). Haddon (1897:23) mentioned that "probably all the [sixteen] skulls" which were submitted to him had been "subjected to artificial deformation", and Harper (1961/2) stated that the 24 crania from Cambridge Hill (as well as those from Richmond Hill and Botany Bay) were intentionally deformed. A similar alteration was performed on the two skulls rescued from Hellshire (Sunday Gleaner, 1992), also housed in the Archaeology Laboratory, and on a second skull from Bull Savannah \# 2 cave in St. Elizabeth (Santos ct al., 2002). At Juan Dolio, a Taino cemetery in the Dominican Republic, there was also recorded a "high incidence of the artificial cranial deformation" (Drusini et al., 1987:249). These alterations can only be produced at an early age when bones are pliable to pressure and can be molded (Harper, 1961/2; Ubelaker, 1989). 


\section{Congenital pathology}

From Y4 Rio Nuevo, St. Mary, was recovered a mandible (Figure 3) with five deciduous teeth (left canine and molars, and the right molars) preserved, and the first left permanent molar could be seen inside the socket. In the anterior part there are four empty alveolus, meaning that those teeth were lost postmortem. Following Ubelaker's (1989) teeth sequence of formation and eruption this individual had an age of 3 or 4 years \pm 24 months at the time of death. However, a deciduous dentition, as well as the adult one, includes four incisors and in this mandible there are only three sockets for them. Thus, this individual has agenesis of a right incisor. The radiograph of this mandible seems to reveal that this congenital absence of tooth will have extended to permanent dentition. According to literature hypodontia is quite common (Hillson, 1996) and is considered "the most frequent hereditary dental anomaly" (Alt and Türp, 1998:111). In the total collection there are fragments of 10 more mandibles, however their fragmentation and tooth loss did not allow a proper search for this parameter.
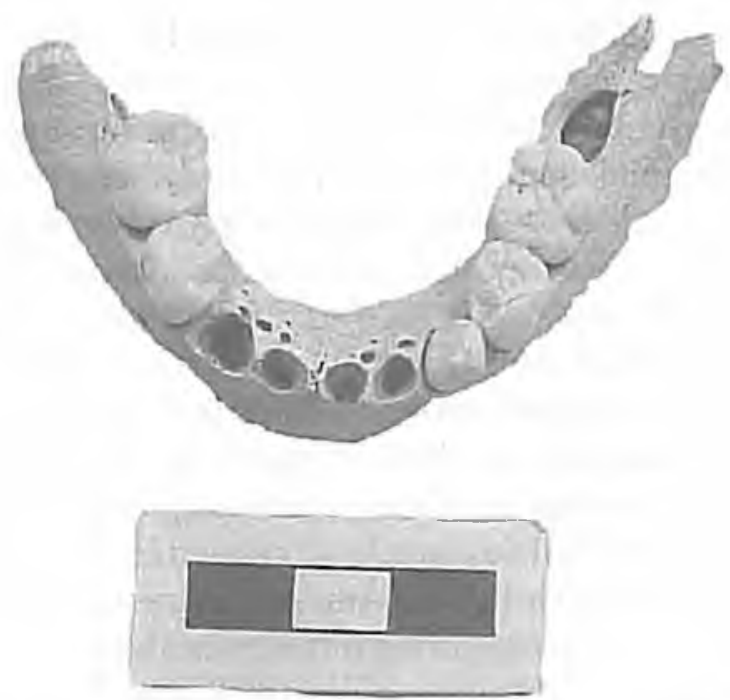

Figure 3. Juvenile mandible Y4B28A.1 from Rio Nuevo, St. Mary Parish showing agenesis of the right incisor. 


\section{Joint diseases}

Osteoarthritis is the commonest joint disease in both modern and ancient populations (Rogers and Waldron, 1995). The two archaeological sites mapped in St. James provided the largest human set (J1 has a minimal number of four individuals, two juveniles and two adults, and JC7 has eight, four juveniles and four adults) and several of those bones have joint disease, namely osteoarthritis with severe cases of eburnation.

In this material from $J 1$, located at Hartfield, joint disease occurred in the body and articular surfaces of several vertebrae (J1B19C.49, J1B19C.50, J1B19C.55, J1B19C.53, J1B19C.54). The atlas J1B19C.56 shows several interesting features: the arcus posterior is about $10 \mathrm{~mm}$ in height and there is eburnation in the right inferior articular surface (Figure 4). Although very slight, in the oleocranon processes of the ulnae (J1B119C.1 and J1B19C.2) there are also signs of osteoarthritis.

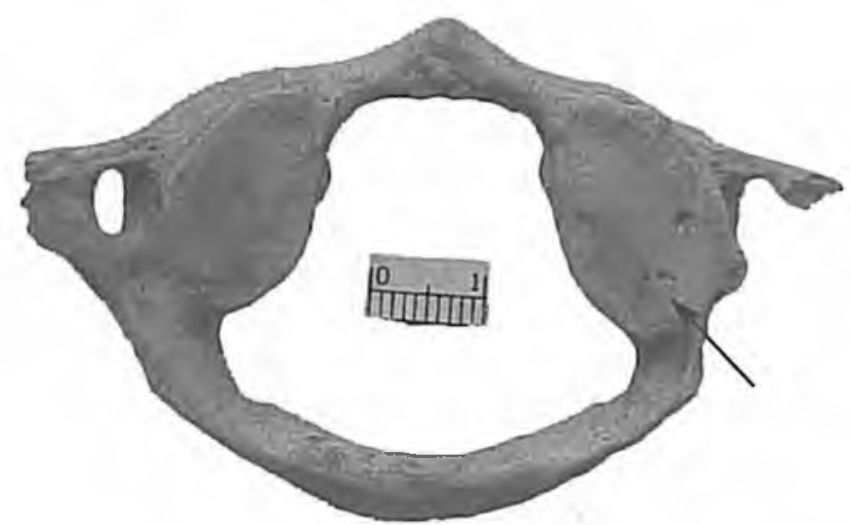

Figure 4. Atlas (J1B19C.56) showing eburnation (arrow) in the right inferior articular facet.

The most striking pathological lesion recorded in St. James, occurred in the left humerus fragment JC7B30A.19 (Figure 5), from an adult individual, found in a cave in Spot Valley. The distal humerus shows signs of osteoarthritis: the capitulum Inmeri - the region that articulates with the head of the radius - presents osteoarthritis eburnation identified by the polished surface that 


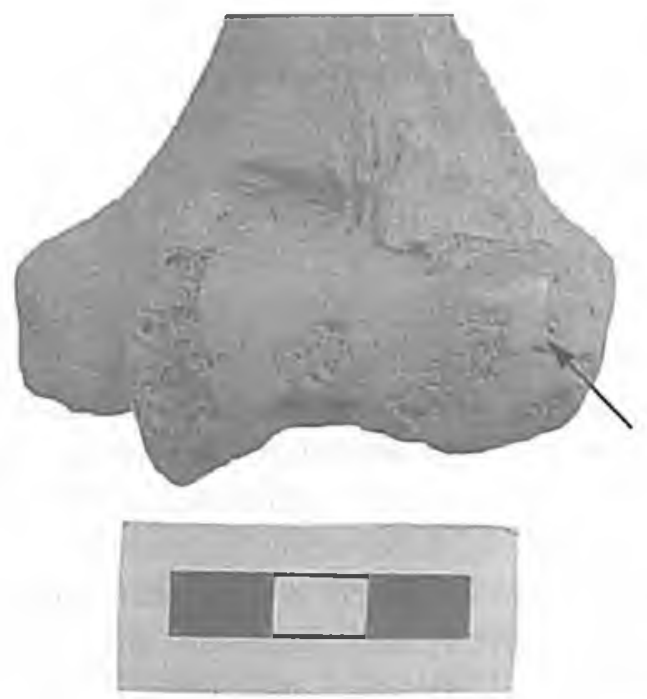

Figure 5. Distal anterior view of a left humerus fragment from Spot Valley (JC7B30A.19) with eburnation in the capitulum bone surface.

results from cartilage degeneration. Despite some postmortem damage it seems that there is also osteoarthritis lipping and porosity in the trochlea. The radial fossa - that receives the head of the radius during maximum flexion of the forearm - is very well marked looking like a "new articulation" area. In the posterior view of the humerus could also be seen bone changes in the oleocranon fossa, which accommodates the oleocranon process of the ulna during forearm extension. Osteoarthritis is also present in the body and superior articular process of a lumbar vertebra (JC7B11.6) from the same site.

An adult femur JC7B19E.1, also from a cave in Spot Valley, presents severe postmortem damage that precludes an accurate evaluation of its surface (Figure 6), namely the existence of pathological change. Several depression lines occurring along the shaft can be the result of plant roots. Moreover; it shows linear grooves that seem more like vessel tracks associated with wellremodeled periostitis. In the patellar articular surface a slight sign of osteoarthritis is visible. 


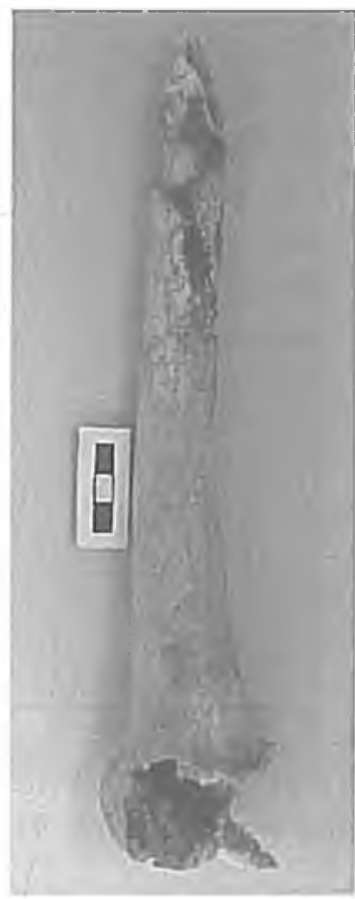

Figure 6. A. Fragment of an adult femur (JC7B19E.1) from Spot Valley cave.

B. Linear grooves on the mid-shaft fragment.

The disarticulated nature of the bones does not permit a decision as to whether they belonged to the same individual, so the cause and exact identification of the phenomena described is impracticable. Nevertheless, it is known that eburnation occurs due to the complete loss of the articular cartilage (Rogers and Waldron, 1995).

Involvement of the lower spine was recorded by Jurmain (1990) in hunting-gathering populations. In the limbs skeleton degenerative joint diseases are most frequent in elbow, knee, hip and foot joints (Aufderheide and Rodríguez-Martín, 1998).

\section{Infectious diseases}

In skeletons from archaeological sites the evidence of infectious lesions, to a greater or lesser degree, are a frequent finding (Roberts and Manchester, 1995). 
Signs of infections were reported on several bones in the Lee Collection. As previously mentioned one femur (JC7B19E.1, from Spot Valley cave) has well-remodeled and healed periostitis. New bone formation was found in a small fragment of fibula shaft from Hartfield (J1B19C.21). Nevertheless, the most remarkable alterations were visible in fragments of long bones from Black River in St. Elizabeth. Among the bone remains recovered from this site are fragments of two tibiae and one fibula, which seem to have belonged to a late adolescent or adult individual(s), with signs of infection. Both right and left preserved fragments of tibiae diaphyses (E12B24.9, E12B24.10) show an increase in thickness in the anterior part of the shaft and a striated appearance of the periosteal reaction (Figure 7). The cross section and the radiograph of those tibiae (Figures $7 \mathrm{~B}$ and 8 ) revealed an enlargement of the anterior part of the shaft, a shape designated as saber shin tibia, and reduction of the marrow cavity.

In one fragment of fibula shaft (E12B24.12) from the same site is also visible a huge increase in thickness of the bone (Figure 9) and well-remodeled periostitis.

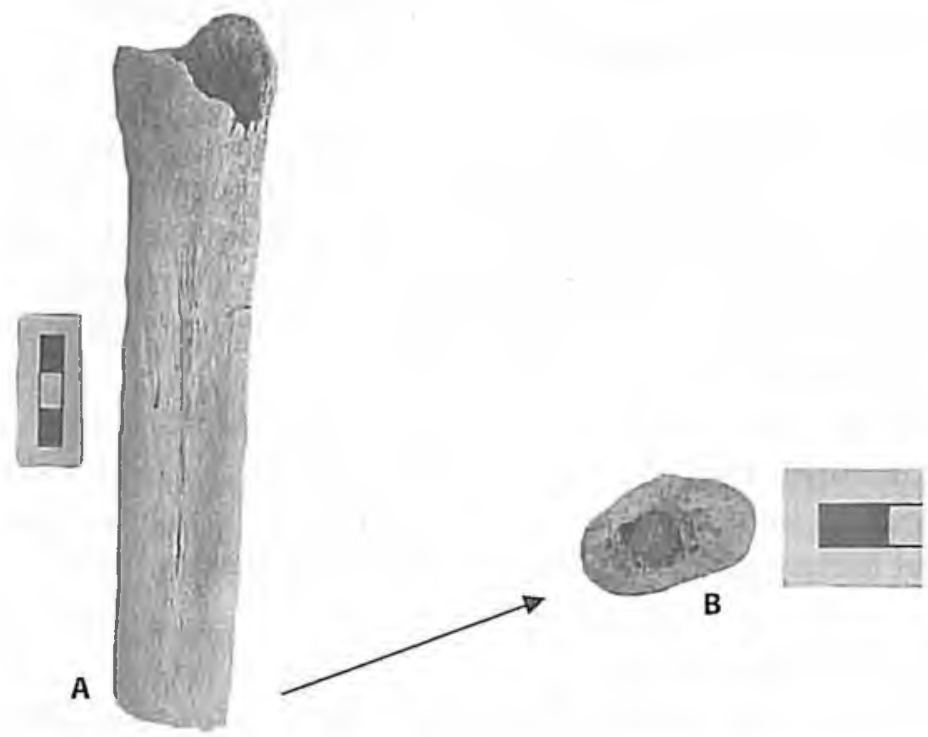

Figure 7. A. Fragment of an adult tibia shaft with periosteal reaction with a striated appearance. B. Circular apposition of bone visible on the tibia cross-section. 
Figure 8. Radiographs reveal the increase of thickness in the anterior part of the shaft in the two tibiae fragments.

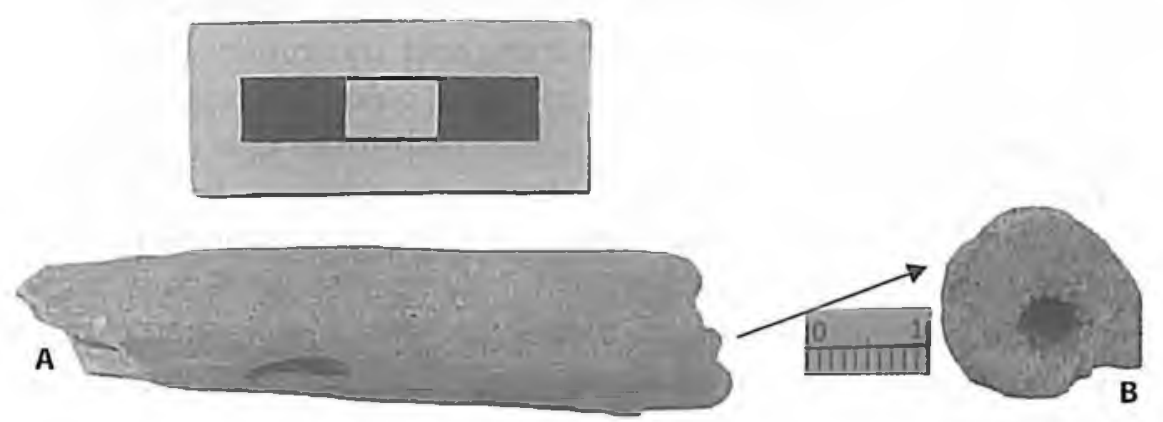

Figure 8. A. Fragment of a fibula shaft with periostitis. B. Cross-5ection showing very thick bone.

Once again, it is not possible to determine whether these bones belonged to the same individual or not, consequently, the aetiology of these lesions remains uncertain. However, such type of conditions could be related to treponemal diseases (Aufderheide 
and Rodríguez-Martin, 1998; Buckley and Dias, 2002). In fact, another possible case of treponematosis has been reported in the second skull from Bull Savannah \#2 cave (EC12), also in St. Elizabeth parish (Santos et al., 2002).

In his study of the human remains from Halberstadt Estate, Flower (1895:608) reported that "one of the largest of the femora has the head greatly enlarged and deformed by chronic rheumatic arthritis (...)" and "one of the left tibiae shows throughout the shaft marked evidence of chronic periostitis, the surface being thickened and vascular. A bone of the opposite side, which might have been of the same individual, shows the same condition in a less marked degree." Moreover, the author states that "none of the bones show any wounds or marks of violence" (Flower, 1895:607).

\section{Final comments}

In the last few decades methodological and theoretical concepts on skeletal analyses have changed considerably. Materials recovered in the past are now being reanalyzed all over the world. Currently, the integration of paleodemography and morbidity data with other aspects of culture makes modern paleodemography and paleopathology holistic sciences (Allsworth-Jones et al., in prep.). This modern study of the history of diseases follows the biocultural approach, that is biological data are interpreted within appropriate cultural contexts which include relevant details of the historical development, local geography, and material culture of the people whose remains are under examination (Roberts and Manchester, 1995).

The results of the paleopathological analysis performed on the Lee Collection human remains are a contribution to our current knowledge about Taino/Arawak health conditions. The characteristics of the analyzed materials, surface findings, very fragmentary and mixed, avoid an attempt to do a differential diagnosis for the lesions present. Moreover, paleopathological investigation should ideally begin during the excavation or exhumation of human remains. Many times, pathological lesions 
are only observable when the bones are first uncovered, because of their fragility and subsequent deterioration when they are removed from the earth. The cultural aspects of the burials should also be carefully recorded (Allsworth-Jones et al., in prep.).

Among the cultural practices noticed on natives from the Greater and the Lesser Antilles is the artificial alteration of their heads (Harper, 1961/2). This modification was reported here in the two preserved crania, both probably from male individuals.

It is known that Tainos buried their dead in open-air-sites and caves, and practiced primary and secondary burials (AllsworthJones et al., in prep.). In the Lee Collection two pots from Belle Air cave (AC4) in St. Ann have bone fragments and teeth and a cranium (CC15B66.1) was found inside a bowl from Taylor's Hut cave in Clarendon (Figure 1). Caves could have been used as burial grounds, as advanced when the site at Halberstadt Estate was discovered (Duerden, 1895; Flower, 1895).

The disarticulated and very fragmentary materials preclude further explanations in the field of paleopathology. Nonetheless, isolated cases could be described. In terms of congenital diseases the absence of a tooth was discerned in the mandible of a juvenile.

Several lesions in the joint were also indicated as evidence of infectious processes. Their differential diagnosis was impracticable. Nevertheless, it is known that the origin of eburnation could be related, among other conditions, to an infectious process or a post-traumatic complication (Rogers and Waldron, 1995). In long bone fragments from leg(s) the increase in thickness resembles evidence of treponematosis.

This contribution to our current knowledge of Taino/Arawak health conditions could be developed with the continuation of fieldwork including (re)analyses of human remains housed in other Jamaican institutions and the study of the non-human bones and teeth that could give information about diet and health conditions. Inferences may also be made about hunting and fishing activities, and their seasonality will help us to understand the scenario of how the Taino/Arawaks lived and died, their culture and the interaction between these people and the natural resources. 


\section{Acknowledgments}

This research was partially supported by a grant from the ViceChancellor of the University of the West Indies. Thanks go to Dr. Wayne West, Head of the Radiology Section, The University Hospital of the West Indies, Mona, Kingston and to Dr. Peter Jolunson and Mrs. Selena McDonald, members of the Section, for their help with the practical carrying out of the radiographs. The Centro de Investigação em Antropologia, University of Coimbra, is also thanked for its contribution.

\section{Bibliography}

Allsworth-Jones, P.; Rodriques, E.; Santos, A. L.; Carlson, L.; Mitchell, S. (in preparation). The Lee Collection CD-ROM inventory.

Allsworth-Jones, P.; Lalor, G.; Lechler, G.; Mitchell, S.; Rodriques, E.; Vutchkov, M. 2001. The Taino settlement of the Kingston Area. In: Gérard, R. (ed.). Proceedings of the XVIIth International Congress for Caribbenn Archaeology. Grenada, 11-17 July 1999. Guadeloupe, Association Internationale d'Archéologie de la Caraíbe: 115-127.

Allsworth-Jones, P.; Wesler, K. 2003. Excavations at Green Castle, Jamaica, 1999-2001. In: Alofs, L.; Dijkhoff, A. C. F. (eds.). Proceetings of the XIXth International Congress for Caribbean Archaeology. Aruba, July 22-28, 2001. Publications of the Archaeological Museum Aruba 9(1): 186-193.

Alt, K. W.; Türp, J. C. 1998. Hereditary dental anomalies. In: Alt, K.W.; Rösing, F. W.; Teschler-Nicola, M. (eds.). Dental anthropology: fundamentals, limits, and prospects. Wien, Springer: 95-128.

Aufderheide, A.; Rodríguez-Martín, C. 1998. The Cambridge Encyclopedin of Human paleopathology. Cambridge, Cambridge University Press.

Buckley, H.; Dias, G. 2002. The distribution of skeletal lesions in treponemal diseases: is the lymphatic system responsible? International Journal of Ostconrchacology, 12: 178-188.

Buikstra, J; Ubelaker, D. (eds.) 1994. Standards for data collection from humnn skeletal remains. Fayetteville, Arkansas, Arkansas Archeological Survey. (Arkansas Archeological Survey Research Series; 44). 
Drusini, A.; Businaro, F.; Calderòn, F. L. 1987. Skeletal biology of the Taino: a preliminary report. International Joumal of Anthropology, 2: 247-253.

Duerden, J. E. 1895. Discovery of aboriginal Indian remains in Jamaica. Nature, 52 (1338): 173-174.

Duerden, J. E. 1897. Aboriginal Indian remains in Jamaica. Joumal of the Irstitute of Jamaica, 2(4): 21-22.

Flower, W. H. 1891. Exhibition of two skulls from a Cave in Jamaica. Journal of the Anthropological Institute of Great Britnin and Ireland, 20: $110-112$.

Flower, W. H. 1895. On recently discovered remains of the aboriginal inhabitants of Jamaica. Nature, 52 (1355): 607-608.

Haddon, A. C. 1897. Note on the craniology of the aborigines of Jamaica. Joumal of the Institute of Jamaica, 2(4): 23-24.

Harper, W. F. 1961/2. Aboriginal Amerindian skulls of Jamaica. Bulletin of the Scientific Resenrch Council, 2(1-4): 66-69.

Hillson, S. 1996. Dental nnthropology. Cambridge, Cambridge University Press.

Jurmain, R. 1990. Paleoepidemiology of a Central California Prehistoric population from CA-ALA-329: II. Degenerative disease. American Journal of Physical Anthropology, 83(1): 83-94.

Kiple, K. F.; Ornelas, K. C. 1996. After the Encounter: disease and demographics in the Lesser Antilles. In: Paquette, R. L.; Engerman, S. L. (eds.). The Lesser Antilles in the Age of European Expansion. Gainesville, University Press of Florida: 50-67.

Lee, J. W. 1964. The Jamaica Columbus found. The Jamaican Historical Society Bulletin, 3(15): 234-243.

Lee, J. W. 1971/3. Burial Cave. Archneology Jamaica, 1-2: 6.

Lee, J. W. 1980. Jamaican Redware. In: Lewenstein, S. M. (ed.). Proceedings of the Eighth International Congress for the Study of the Pre-Columbian Cultures of the Lesser Antilles. St. Kitts, 1979. Tempe, Arizona State University: 597-609. (Anthropological Research Papers; 22).

Lee, J. W. 1990. Petroglyphs of Jamaica. In: Tekakis, A. G. P.; Arenas, I. V.; Obediente, M.S. (eds.). Proceedings of the Elewenth Congress of the International Association for Caribbean Archaeology. San Juan, 1985. University of Puerto Rico, U. S. Department of Agriculture, and La Fundacion Arqueologica, Antropologica e Historica de Puerto Rico: 153-161. 
Roberts, C.; Manchester, 1995. The archneology of disense. $2^{\text {nd }}$ ed. IthacaNew York, Alan Sutton Publishing Limited-Cornell University Press. Rogers, J.; Waldron, T. 1995. A ficld guide to joint disease in nrchneology. West Sussex, John Wiley \& Sons, Ltd.

Santos, A. L. 2001. Green Castle burials: antiropological report. Kingston, Jamaica. [Unpublished report].

Santos, A. L. 2003. Human remains in the Lee Collection. Kingston, Jamaica. [Unpublished report].

Santos, A. L.; Gardner, M.; Allsworth-Jones, P. 2002. A possible case of treponematosis in a Taino/Arawak skull from Jamaica. In: $14^{l t h}$ European Mecting of the Palcopathology Associntion: Program - Abstract. Coimbra, 28-31 August 2002. Coimbra, Departamento de Antropologia, Universidade de Coimbra: 144.

Silverberg, J.; Vanderwal, R. L.; Wing, E. S. 1972. The White Marl site in Jamaica: report of the 1964 Robert $R$. Howard excauation. Department of Anthropology, The University of Wisconsin-Milwaukee. [Unpublished report].

Sturtevant, W. C. 1961. Taino agriculture. In: Wilbert, J. (ed.). The ciolution of horticultural systems in native South America: causes and consequences - $A$ Sympositnm. Caracas, Sociedad de Ciencias Naturales La Salle: 69-82. Sunday Gleaner 1992. Skeletons, gold found in Hellshire cave. July, 19. The James W. Lee Collection of Arainak Artefncts 2000. Pamphlet produced for the handing over ceremony July 23, 2000 at The Undercroft. Mona, The University of the West Indies.

Ubelaker, D. 1989. Human skeletal remains. $2^{\text {nd }}$ ed. Washington, D. C., Taraxacum Press. 